\title{
Effect of incorporation of Finger millet (Eleusine coracana) on the antimicrobial, ACE inhibitory, antioxidant and antidiabetic potential of a milk- millet composite probiotic fermented product
}

\author{
Jinal Kesharbhai Chaudhary and Sreeja Mudgal \\ Received: 20 February 2020 / Accepted: 31 March 2020 / Published online: 12 July 2020 \\ (c) Indian Dairy Association (India) 2020
}

\begin{abstract}
The aim of this research was to evaluate the effect of incorporation of finger millet on anti-microbial, ACE inhibitory, antioxidant and antidiabetic potential of milk-millet composite product. Malted, heated finger millet flour was incorporated in the milk @ $20 \%$. The mix was fermented using culture comprising of Streptococcus thermophilus MTCC 5460 and probiotic strain Lactobacillus helveticus MTCC 5463 @2\%. Product without finger millet was the control. Products were evaluated for antimicrobial, ACE inhibitory, antioxidant and antidiabetic potential using standard procedures. Incorporation of finger millet significantly $(\mathrm{P}<0.05)$ improved the antimicrobial, antioxidant and antidiabetic activity of the composite product. The product showed a significantly $(\mathrm{P}<0.05)$ higher antimicrobial activity against all test pathogens in comparison to control. The antioxidant activity of composite food and control were $95.59 \%$ and $52.37 \%$ respectively. Antidiabetic potential measured in terms of $\alpha$-amylase inhibition and $\alpha$-glucosidase inhibition revealed that incorporation of finger millet significantly improved the $\alpha$-glucosidase inhibition (69.89\%) in comparison to control (51.89\%), whereas the $\alpha$-amylase inhibition was not significant. The ACE inhibitory activity of composite product and control were found to be 51.54 and $51.11 \%$ respectively, which did not differ significantly. Incorporation of finger millet adds to the functional value of resulted composite food. The results of this study open promising prospects for use of such composite product as functional food.
\end{abstract}

Dairy Microbiology Department, SMC College of Dairy Science, Anand Agricultural University, Anand-388 110, Gujarat, India

Sreeja Mudgal $(\bowtie)$

Dairy Microbiology Department, SMC College of Dairy Science, Anand Agricultural University, Anand-388 110, Gujarat, India

Email: sreejamudgal@aau.in,sreeja_p70@rediffmail.com
Keywords: Antioxidant, Antidiabetic, Finger millet, Functional food, Milk-millet composite product

\section{Introduction}

The worldwide market for functional foods continues to increase in response to the demands of an increasingly health conscious public. Fermented milk products containing probiotics have grown into one of the leading categories of functional foods (Begum et al. 2017). Both milk and probiotics are reported to play significant roles in the prevention and management of non-communicable diseases. Even though fermented milk is considered superior in its nutritional and health benefits, it is deficient in micronutrients such as iron and vitamin $\mathrm{C}$ and dietary fiber components known for its prebiotic effect. Such deficiency can be overcome to a great extent through fortification of milk with cereals such as finger millet (Eleusine coracana). Finger millet is a low cost millet with practically no reports of its adverse effect. Further, it is reported to have higher dietary fiber content, several micronutrients and phytonutrients (Tripathi and Platel, 2010; Shobana et al. 2013). Hence, the cereal can be a good ingredient for use along with milk for developing a milk cereal-based functional food.

Finger millet (Eleusine coracana) is a very common millet found in different parts of world. This millet has recently been assigned the status of nutri-cereals (The Gazette of India, 2018). Finger millet is very rich in calcium (some genotypes of finger millet have been reported to contain calcium as high as $450 \mathrm{mg} / 100 \mathrm{~g}$ of grains), phosphorus (283 $\mathrm{mg} \%$ ), potassium (408 $\mathrm{mg} \%$ ) and contains iron (3.9 $\mathrm{mg} \%$ ), dietary fiber, vitamins, as well as useful amounts of copper and comparatively higher chromium, magnesium, molybdenum, zinc and selenium. (Gopalan et al. 2009; Tripathi and Platel, 2010; Gupta et al. 2011; Gupta et al. 2017). Finger millet is comparable to rice with regard to protein (6-8\%) and fat $(1-2 \%)$ and is superior to rice and wheat with respect to mineral and micronutrient contents and essential amino acids such as methionine and tryptophan (Verma and Patel, 2013; Gupta et al. 2017). The seed coat of finger millet is reported to be rich in phytochemicals like polyphenols (Devi et al. 2014) which contributes to antioxidant, anticancer and antidiabetic activities. High fiber in the millet is reported to promote slow digestion and 
prevent constipation, high cholesterol formation, diabetes and intestinal cancer (Devi et al. 2014). Being a rich source of calcium and iron, and the fact that the bioavailability can be improved by simple processing such as germination and fermentation, finger millet is considered as a good supplement for improving bone health and haemoglobin. It is recognized for its health benefitting properties such as antimicrobial (Chethan and Malleshi, 2007; Varsha et al. 2009), antioxidant (Chandrasekara and Shahidi, 2011; Veenashri and Muralikrishna, 2011), cholesterol lowering (Pore and Magar, 1976), blood glucose lowering effect (Shobana et al. 2009), nephroprotective and anti-cataractogenic (Shobana et al. 2013). Earlier it was believed that polyphenols, phytates, tannins and dietary fiber contents of finger millet act as anti-nutrients because of their metal chelating and enzyme inhibition activities but now it has been confirmed that these constituents can contribute to antioxidant activity, which is an important factor in resisting aging and metabolic diseases (Chandra et al. 2016). Regular consumption of finger millet product is reported to decrease fasting glucose by $32 \%$ and eliminate insulin resistance by $43 \%$ (Chandra et al. 2016).

Looking to the nutritional and functional aspects of finger millet, its incorporation in milk and the probiotic fermentation of this milk-millet mixture can result in a composite fermented food having improved nutritional and functional value. Many in vitro and in vivo study reports are available on the health benefits of fermented milks and finger millet. But very few research works have been carried out in combining the nutritional aspects of milk, finger millet, probiotics and lactic acid bacterial fermentation as well as in vitro functional evaluation of millet enriched probiotic fermented milk. Hence in the current research, the effect of incorporation of finger millet on the sensory attributes, physicochemical parameters, microbial count, status of phytic acid and tannin and functional properties such as antimicrobial, ACE inhibitory, antioxidant and antidiabetic potential of the milk-millet composite probiotic fermented product was studied.

\section{Materials and Methods}

\section{Bacterial strains}

Starter culture (Streptococcus thermophilus MTCC 5460 and probiotic strain Lactobacillus helveticus MTCC 5463) used in the study was obtained from the culture collection of Dairy Microbiology department, SMC College of Dairy Science, Anand Agricultural University, Anand, Gujarat, India. Individual strains were propagated in sterilized reconstituted skim milk (11\% total solids) medium by incubation at $37 \pm 1^{\circ} \mathrm{C}$ for $6 \mathrm{~h}$ and stored at $5 \pm$ $2^{\circ} \mathrm{C}$. Three successive transfers of cultures were given in the same medium prior to their use to ensure activity of cultures during the course of study.

\section{Materials}

Toned milk (Fat-3 \%, SNF-8.5 \%) was obtained from Vidya shoppe, Anand, Gujarat. Finger millet variety PRM 9802 (dark brown colored) of AGMARK (Grade I) was procured from local supermarket of Anand, Gujarat, India.

\section{Preparation of malted finger millet flour}

Malting of finger millet was carried out according to the procedure suggested by Shaikh et al. (2017). Finger millet grains were cleaned to remove extraneous matter. The grains were washed and steeped in water for $12 \mathrm{~h}$ at $30 \pm 2{ }^{\circ} \mathrm{C}$ (Grains to water proportion $1: 3)$. Water was changed after every $4 \mathrm{~h}$. Steeped grains were then drained and spread on perforated trays lined with muslin cloth and kept in the BOD incubator at $25 \pm 2{ }^{\circ} \mathrm{C} / 24 \mathrm{~h}$ for germination. The germinated grains were then vacuum tray dried ( $42 \pm 3{ }^{\circ} \mathrm{C}$ at 640 to $660 \mathrm{~mm} \mathrm{Hg}$ of vacuum), ground to form a fine powder and sieved (100 $\mu$ mesh size) to obtain malted finger millet flour.

\section{Preparation of milk-millet composite probiotic fermented product}

Toned milk (3.0\% Fat, $8.5 \%$ SNF) was heated to $90^{\circ} \mathrm{C} / 10 \mathrm{~min}$ and cooled to $40^{\circ} \mathrm{C}$. This milk was added with malted, heated $\left(70^{\circ} \mathrm{C} / 2\right.$ min) finger millet flour @ 20\% on milk basis. It was then mixed to ensure uniform mass. The mixture was then heated to $70^{\circ} \mathrm{C}$ for no hold and further cooled to $40^{\circ} \mathrm{C}$ and inoculated with starter culture (a) $2 \%$. It was incubated at $\left(37 \pm 2{ }^{\circ} \mathrm{C}\right)$ till titratable acidity reached to about $0.7 \%$ lactic acid (LA). The product was then cooled ( $5 \pm$ $2{ }^{\circ} \mathrm{C}$ ) and the curd was broken to obtain a uniform viscous product. It was filled in HDPE bottles and stored at refrigeration temperature $\left(7 \pm 1^{\circ} \mathrm{C}\right)$.

\section{Titratable acidity and $\mathrm{pH}$}

Titratable acidity of the product was determined after mixing $10 \mathrm{~g}$ of samples with $10 \mathrm{ml}$ of distilled water and titrated against $0.1 \mathrm{~N}$ $\mathrm{NaOH}$ using 1 per cent (w/v) phenolphthalein as an indicator. The results were expressed as per cent lactic acid (IS: 1479-1, 1960). $\mathrm{pH}$ of the product was measured using a $\mathrm{pH}$ meter (Oakton pH 700 Benchtop Meter, Mumbai, India). Fermentation time was measured as time required to reach $\mathrm{pH} 4.7 \pm 0.1$ or 0.7 per cent lactic acid expressed as hours.

\section{Viscosity}

Viscosity of the fermented milk products $\left(200 \mathrm{~g}\right.$ each) at $25^{\circ} \mathrm{C}$ was measured using Brookfield viscometer (LVDV-E Viscometer, Brookfield, Borivali East, Mumbai, India) with a constant shear rate using spindle No. 61s at 100 RPM. Viscosity of the samples was expressed as centipoise. 


\section{Microbiological analysis}

Eleven grams of product was aseptically weighed and transferred to $99 \mathrm{ml}$ sterile phosphate buffer to obtain 1:10 dilution. Subsequently, $1 \mathrm{ml}$ of above dilution was used for making further dilutions in $9 \mathrm{ml}$ phosphate buffer tubes. Suitable dilutions were prepared and poured in a set of sterile Petri dishes in duplicates. For the enumeration of Probiotic count, $1.0 \mathrm{ml}$ from selected dilutions were poured in duplicate plates and mixed with sterile cooled deMan, Rogosa and Sharpe (MRS) agar. After setting of the agar, another layer of the same medium $(5-7 \mathrm{ml})$ was poured. The plates were then incubated at $37 \pm 2{ }^{\circ} \mathrm{C}$ for $72 \mathrm{~h}$. After incubation, the typical lactobacilli colonies in the plates were counted and the count was expressed as log cfu/g (IS: 1479, 1962). For the enumeration of Streptococcal count, in place of MRS agar, M17 agar was used.

\section{Sensory evaluation}

Fermented products were subjected to sensory evaluation by expert panel of judges $(\mathrm{n}=8)$ for various sensory attributes, viz., flavor, body and texture, acidity, color and appearance, and overall acceptability criteria using 9-point hedonic scale described by Stone and Sidel (2004). Coded samples of freshly prepared products were given to the panel of judges. The judges were asked to rank the products from 1 to 9 according to their liking preference using 9-point hedonic scale rating.

\section{Tannin estimation}

Tannin content of malted finger millet flour, unmalted finger millet flour and probiotic fermented milk enriched with finger millet were estimated by the Folin-Denis method (Swain and Hillis, 1959). Standard solution of tannic acid $(0.1 \mathrm{mg} / \mathrm{ml})$ was taken in aliquots of $0,1.5,2.0,2.5$ and $3 \mathrm{ml}$ in five volumetric flask of $100 \mathrm{ml}$ each containing $75 \mathrm{ml}$ distilled water. $5 \mathrm{ml}$ of Folin-Denis reagent was added and the contents were shaken well. $10 \mathrm{ml}$ of saturated $\mathrm{Na}_{2} \mathrm{CO}_{3}$ solution was added to each flask, and the volume made up to $100 \mathrm{ml}$ with distilled water. The contents were mixed thoroughly and the absorbance was measured at $760 \mathrm{~nm}$ using spectrophotometer (Systronics 2206, Ahmedabad, India). For the preparation of sample, $2.5 \mathrm{~g}$ of probiotic fermented milk enriched with finger millet, $0.5 \mathrm{~g}$ malted and $0.5 \mathrm{~g}$ unmalted finger millet flours were weighed separately in $250 \mathrm{ml}$ conical flasks and $75 \mathrm{ml}$ of distilled water was added to each conical flasks. Contents were mixed properly and the samples were boiled for $30 \mathrm{~min}$. Then the contents were filtrated using Whatman no. 2 filter paper and the volume made up to $100 \mathrm{ml}$ with distilled water. $0.5 \mathrm{ml}$ of this solution was used for estimation of tannin content in a $10 \mathrm{ml}$ volumetric flask. $0.5 \mathrm{ml}$ Folin-Denis reagent and $1 \mathrm{ml}$ of saturated solution of $\mathrm{Na}_{2} \mathrm{CO}_{3}$ was added and the volume made up to $10 \mathrm{ml}$. The contents were mixed thoroughly and kept undisturbed for $30 \mathrm{~min}$. The absorbance was measured at $760 \mathrm{~nm}$ using a spectrophotometer. The percent tannin content was calculated using the formula given below.

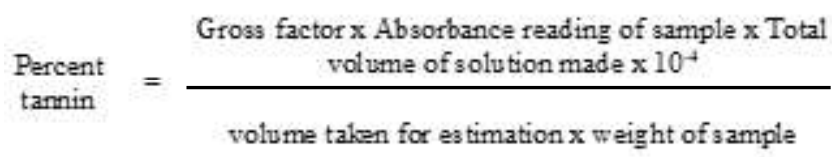

\section{Phytic acid estimation}

Phytic acid content of the product and finger millet flours was estimated by titrimetric method (Lolas and Markakis, 1975). $2.5 \mathrm{~g}$ of probiotic fermented milk enriched with finger millet, $0.5 \mathrm{~g}$ each of malted and unmalted finger millet flours was taken in separate $100 \mathrm{ml}$ flasks and $10 \mathrm{ml}$ of $2 \%$ hydrochloric acid was added to each flasks. The contents were mixed well and kept for $3 \mathrm{~h}$. It was filtered properly using Whatman no. 2 filter paper and $5 \mathrm{ml}$ filtrate was taken into $100 \mathrm{ml}$ flask and $1 \mathrm{ml}$ distilled water was added, mixed well and $10 \mathrm{ml} 0.3 \%$ ammonium thiocynate indicator was added. This was titrated against iron dichloride solution containing $0.00195 \mathrm{~g}$ iron per $\mathrm{ml}$. The end point noted was yellow colour. Phytic acid content was calculated using formula given below.

Per cent Phytic acid $=y \times 1.19 \times 100$

Where, $\mathrm{y}=$ Titre value $\times 0.00195 \mathrm{~g}$

\section{Antimicrobial activity}

Antimicrobial activity of the fermented product was tested by agar well diffusion method (Delgado et al. 2001) with some modifications. The antimicrobial activity of the products were tested against Bacillus cereus, Escherichia coli, Salmonella typhi, Listeria monocytogenes, and Staphylococcus aureus (All the strains were obtained from Department of Dairy Microbiology, S.M.C. College of Dairy Science, Anand, Gujarat, India). $100 \mu \mathrm{l}$ of each indicator strains were poured into the petri dish followed by adding 15 to $20 \mathrm{ml}$ of Nutrient agar and allowed to solidify or the plates were refrigerated at $5{ }^{\circ} \mathrm{C}$ for $10-15 \mathrm{~min}$ before wells were punched out of the agar with sterile borer (Himedia, diameter$15 \mathrm{~mm}$ ). $100 \mu \mathrm{l}$ fermented milk samples were then filled into the wells to check their inhibition activities on all five strains. The plates were once again refrigerated at $5{ }^{\circ} \mathrm{C}$ for 10 to $15 \mathrm{~min}$ to facilitate the diffusion of fermented milk samples and were incubated at $37^{\circ} \mathrm{C}$ for $24 \mathrm{~h}$. The inhibition activities of fermented milk samples on the indicator strains were indicated by the presence of a clear zone surrounding the agar wells. The zone of inhibition around the wells was measured in $\mathrm{mm}$.

\section{Angiotensin Converting Enzyme (ACE) inhibitory activity}

ACE-inhibitory activity (ACEi \%) of the fermented products was determined according to the method described by Hati et al. (2015) with some modifications. An aliquot of $200 \mu \mathrm{l}$ of product supernatant collected after centrifuging at $14000 \mathrm{rpm}$ for $20 \mathrm{~min}$ 
was added to $20 \mu \mathrm{l}$ of ACE ( $4 \mathrm{mU}$ in $250 \mu \mathrm{l})$ and then incubated for $10 \mathrm{~min}$ at $37^{\circ} \mathrm{C}$ in eppendorf, before $50 \mu 15 \mathrm{mM} \mathrm{N}$-Hippuryl-HisLeu (HHL) was added. The mixture was gently stirred and then incubated at $37^{\circ} \mathrm{C}$ for $60 \mathrm{~min}$. The reaction was ended by adding $500 \mu \mathrm{l}$ of $1 \mathrm{~N}$ chilled $\mathrm{HCl}$. The $635 \mu \mathrm{l}$ of mixture was transferred into another eppendorf, added with $850 \mu$ l of ethyl acetate followed by centrifugation at 14000 RPM for $20 \mathrm{~min}$. The aqueous layer was transferred into another eppendorf and then dried on water bath at $85^{\circ} \mathrm{C}$. The residual hippuric acid was dissolved in $2 \mathrm{~mL}$ of deionized water and it was filtered through $0.45 \mu \mathrm{m}$ membrane filter (Millex ${ }^{\circledR}$ - HV, MERK Ireland). The absorbance of the solution was measured spectrophotometrically (Systronics 2206, Ahmedabad, Gujarat, India) at $228 \mathrm{~nm}$. The activity of each sample was tested in triplicate. The percent ACE inhibition was calculated using the following formula.

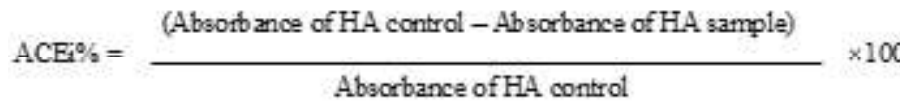

Where, HA control was the absorbance of hippuric acid produced by the ACE in buffer without lactic cultures. HA sample was the absorbance of hippuric acid produced by the ACE in the presence of lactic cultures.

\section{Antioxidant activity}

Antioxidant activity was measured by using 2, 2'-Azino-bis 3ethylbenzothaizoline-6-sulfonic acid (ABTS) Assay with some modifications. Total radical scavenging capacity was based on the ability of a compound to scavenge the stable ABTS radical in $10 \mathrm{~min}$ (Re et al. 1999). The ABTS working solution was prepared by mixing $88 \mu$ of $140 \mathrm{mM}$ potassium persulphate with $5 \mathrm{ml}$ of $7 \mathrm{mM}$ ABTS stock solution and incubating overnight in dark bottles for generation of radicals. Then it was diluted with phosphate buffer saline (PBS) to adjust the absorbance at 734 $\mathrm{nm}$ to $0.7 \pm 0.02$. An aliquot of $25 \mu \mathrm{l}$ of product (for control $230 \mu \mathrm{l}$ ) supernatant collected after centrifuging at $14000 \mathrm{rpm}$ for $30 \mathrm{~min}$ was mixed with $2270 \mu \mathrm{l}$ ABTS and made up to $2500 \mu \mathrm{l}$ with PBS solution. The decrease in absorbance at $734 \mathrm{~nm}$ was recorded over period of $6 \mathrm{~min}$ at $30 \mathrm{sec}$ interval using spectrophotometer. Percent inhibition of absorbance at $734 \mathrm{~nm}$ was calculated using the following formula.

ABTS $^{+}$
scavenging
activity
$(\%)=$

\section{Antidiabetic activity}

Antidiabetic activity was measured in terms of $\alpha$-Amylase and $\alpha$ Glucosidase inhibition.

\section{$\alpha$-Amylase inhibition assay}

Amylase activity was assayed by the spectrophotometric method using 3, 5 dinitrosalicylic acid (Pinto et al. 2010). Sample extracts $(300 \mu \mathrm{l})$ were taken in test tubes, to that, $70 \mu \mathrm{L}$ of $50 \%$ methanol, $50 \mu \mathrm{L}$ of enzyme solution and $1 \mathrm{~mL}$ of starch solution was added and incubated at $37^{\circ} \mathrm{C}$ for 5 minutes. 3, 5 Dinitrosalycylic Acid (DNSA) reagent $(2 \mathrm{ml})$ was added and the tubes were heated in boiling water bath for 5 minutes followed by cooling to room temperature. The absorbance of the colour developed was read at $540 \mathrm{~nm}$. Blank and control tubes were also set up simultaneously without enzyme and sample, respectively.

$$
\% \text { inhibition of oramylase }=\frac{\text { (O.D. Control-O.D. S ample) }}{\text { OD. Control }} \times 100
$$

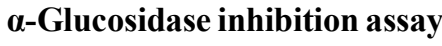

The assay was performed according to the method given by $\mathrm{McCue}$ et al. (2005). The assay mixture consisting of different concentrations of sample extracts $(500 \mu \mathrm{g} / \mathrm{ml})$ and $1000 \mu \mathrm{l}$ of 0.1 $\mathrm{M}$ phosphate buffer ( $\mathrm{pH}$ 6.9) containing $\alpha$-glucosidase solution $\left(1 \mathrm{U} / \mathrm{ml}\right.$ ) was incubated at $25^{\circ} \mathrm{C}$ for $10 \mathrm{~min}$. After pre-incubation, $500 \mu \mathrm{l}$ of $5 \mathrm{mM}$ para nitrophenyl- $\alpha$-D-glucopyranoside solution in $0.1 \mathrm{M}$ phosphate buffer ( $\mathrm{pH} 6.9$ ) was added and incubated at $25{ }^{\circ} \mathrm{C}$ for $5 \mathrm{~min}$. Before and after incubation, absorbance was recorded at $405 \mathrm{~nm}$ using UV spectrophotometer and compared to a control containing $500 \mu \mathrm{l}$ buffer solutions instead of the extract. The $\alpha$-glucosidase inhibitory activity (\%) was calculated as following:

$$
\% \text { inhibition of } \alpha \text {-glucosidase }=\frac{\text { O.D. Control }- \text { O.D. Sample }}{\text { O.D. Control }} \times 100
$$

\section{Statistical analysis}

The data related to chemical, sensory and functional aspects of probiotic fermented products were analyzed using statistical design CRD and Factorial completely randomized design (FCRD) as per Steel and Torrie (1980). The values for microbial counts were $\log$ transformed before analysis.

\section{Results and Discussion}

The results of analyses of finger millet enriched product and control for sensory attributes, physico-chemical parameters, microbial count, phytic acid and tannin are shown in Tables 1, 2 and 3. The products were subjected to judging and grading for sensory attributes viz., (i) flavour, (ii) body and texture, (iii) acidity, (iv) colour and appearance and (v) overall acceptability by expert panel of judges using 9-pont Hedonic scale. Scores obtained for sensory attributes of fermented products are shown in Table 1. 
Both products were liked by the judges and the difference in their flavor scores were found to be not significant. But a significant $(\mathrm{P}<0.05)$ difference was seen in the scores of all other attributes, which were higher in case of finger millet enriched product (T1). This may be because, the finger millet enriched product was found more viscous and uniform in body and texture in comparison to control (T2) sample. Acidity scores of the products as perceived by the judges differed significantly $(\mathrm{P}<$ 0.05). The mean values for $\mathrm{T} 1$ and $\mathrm{T} 2$ were 8.45 and 7.45 respectively. Colour and appearance is one of the important attributes of sensory quality. A significant $(\mathrm{P}<0.05)$ difference was seen in the colour and appearance score of both products. Because of its viscous and uniform nature, finger millet enriched product scored higher for color and appearance. Overall acceptability of $\mathrm{T} 1(8.43 \pm 0.160)$ was significantly $(\mathrm{P}<0.05)$ higher than T2 $(7.64 \pm 0.238)$ indicating the high sensory acceptability of the product.

Statistically there was no significant $(\mathrm{P}>0.05)$ difference found in the $\mathrm{pH}$ and titratable acidity of products (Table 2). $\mathrm{pH}$ of the freshly prepared fermented products ranged from 4.77 to 4.78 while the titratable acidity ranged from 0.71 to 0.73 per cent lactic acid. The Lactobacillus (probiotic) and streptococcal counts were significantly $(\mathrm{P}<0.05)$ higher in finger millet enriched product compared to control. This may be due to the better nutrient availability to the cultures in the milk- millet composite food. Lactic acid bacteria are fastidious in their nutritional requirements, and cereals in general are reported to have higher content of some of the essential vitamins, minerals and dietary fibre than in milk. Further, malted millet is reported to be a good source of amylases and during germination, the amylases partially hydrolyze the starch to lower molecular weight carbohydrates such as oligo- and disaccharides. When this malted flour is mixed with milk and heated, the amylases hydrolyze the starch to simple sugars which the lactic acid bacterial strains can utilize for their growth (Shobana et al. 2013; Shaikh et al. 2017). There was no scientific published data on similar kind of work available to compare the effect of finger millet incorporation on streptococcal and probiotic counts of fermented milk product. The apparent viscosity (cp) of T1 and T2 were $33.29 \mathrm{cp}$ and $29.64 \mathrm{cp}$ respectively.

Status of phytic acid and tannin in the unmalted finger millet flour, malted finger millet flour and finger millet enriched probiotic fermented product is shown in Table 3. In comparison to the unmalted finger millet flour, malted finger millet flour has shown a reduction of $40.21 \%$ and $18.21 \%$ in the phytic acid and tannin content respectively. In the finger millet enriched probiotic fermented product, the reduction in the phytic acid and tannin content was $45.97 \%$ and $81.35 \%$ percent respectively in comparison to malted finger millet flour and the reduction was $67.69 \%$ and $84.76 \%$ respectively when compared to unmalted finger millet flour. In our product preparation, we have used malted finger millet flour. The processes such as soaking, germination and fermentation are reported to reduce the anti-nutritional factors like phytic acid and tannin in finger millet (Devi et al. 2014; Chaudhary and Vyas, 2014). It has been reported that tannin and phytic acid in finger millet might reduce the bioavailability of nutrients (iron, calcium, zinc, magnesium) and significantly influence the functional and nutritional properties of millet containing foods (McDonough et al. 2000). Tannin is considered undesirable because it precipitate protein, inhibit digestive enzymes and affect the utilization of vitamins and minerals. The dosage of tannin is critical to these effects (Chung et al. 1998). Phytic acid binds to minerals and makes them unavailable due to its chelating property. It has been reported that phytic acid inhibits absorption of iron, zinc, calcium, magnesium and manganese (Phillippy, 2006). Hence removal of phytic acid increases bioavailability of many cations and thus nutritional value of food. Mbithi-Mwikya et al. (2000) reported that sprouting of finger millet results in lowering of the

Table 1 Sensory attributes of the fermented products evaluated using 9-point hedonic scale (1-9)

\begin{tabular}{lllllc}
\hline $\begin{array}{l}\text { Test } \\
\text { Products }\end{array}$ & Flavor & $\begin{array}{l}\text { Body \& } \\
\text { Texture }\end{array}$ & Acidity & $\begin{array}{l}\text { Color \& } \\
\text { Appearance }\end{array}$ & $\begin{array}{c}\text { Overall } \\
\text { Acceptability }\end{array}$ \\
\hline T1 & $8.19 \pm 0.12^{\mathrm{a}}$ & $8.42 \pm 0.24^{\mathrm{a}}$ & $8.45 \pm 0.25^{\mathrm{a}}$ & $8.52 \pm 0.16^{\mathrm{a}}$ & $8.43 \pm 0.16^{\mathrm{a}}$ \\
$\mathrm{T} 2$ & $8.10 \pm 0.29^{\mathrm{a}}$ & $7.78 \pm 0.24^{\mathrm{b}}$ & $7.45 \pm 0.42^{\mathrm{b}}$ & $7.97 \pm 0.09^{\mathrm{b}}$ & $7.64 \pm 0.24^{\mathrm{b}}$ \\
\hline
\end{tabular}

The results are indicated as mean \pm standard deviation $(n=7) . T 1=$ Product with finger millet, T2= product without finger millet. Different letters in the same column indicate significant differences $(\mathrm{p}<0.05)$.

Table 2 Physico-chemical parameters and microbial count of the fermented products

\begin{tabular}{llllll}
\hline $\begin{array}{l}\text { Test } \\
\text { products }\end{array}$ & $\begin{array}{l}\text { Titratable } \\
\text { acidity }(\% \mathrm{LA})\end{array}$ & $\mathrm{pH}$ & $\begin{array}{l}\text { Probiotic count } \\
(\log \mathrm{cfu} / \mathrm{g})\end{array}$ & $\begin{array}{l}\text { Streptococcal } \\
\operatorname{count}(\log \mathrm{cfu} / \mathrm{g})\end{array}$ & $\begin{array}{l}\text { Viscosity } \\
\left(\mathrm{cp} \mathrm{at} 25^{\circ} \mathrm{C}\right)\end{array}$ \\
\hline T1 & $0.73 \pm 0.01^{\mathrm{a}}$ & $4.77 \pm 0.09^{\mathrm{a}}$ & $10.07 \pm 0.09^{\mathrm{a}}$ & $9.88 \pm 0.07^{\mathrm{a}}$ & $33.29 \pm 0.37^{\mathrm{a}}$ \\
$\mathrm{T} 2$ & $0.71 \pm 0.01^{\mathrm{a}}$ & $4.78 \pm 0.08^{\mathrm{a}}$ & $9.34 \pm 0.07^{\mathrm{b}}$ & $9.64 \pm 0.04^{\mathrm{b}}$ & $29.64 \pm 0.21^{\mathrm{b}}$ \\
\hline
\end{tabular}

The results are indicated as mean \pm standard deviation $(n=7)$. T1= Product with finger millet, T2= product without finger millet. Different letters in the same column indicate significant differences $(\mathrm{p}<0.05)$. 
Fig 1. Antimicrobial activity of product with finger millet (T1) and without finger millet (T2) against test pathogens. Values are given as mean $\pm \mathrm{SD}(\mathrm{n}=4)$. Letters (a, b) indicate significant differences $(p<0.05)$.

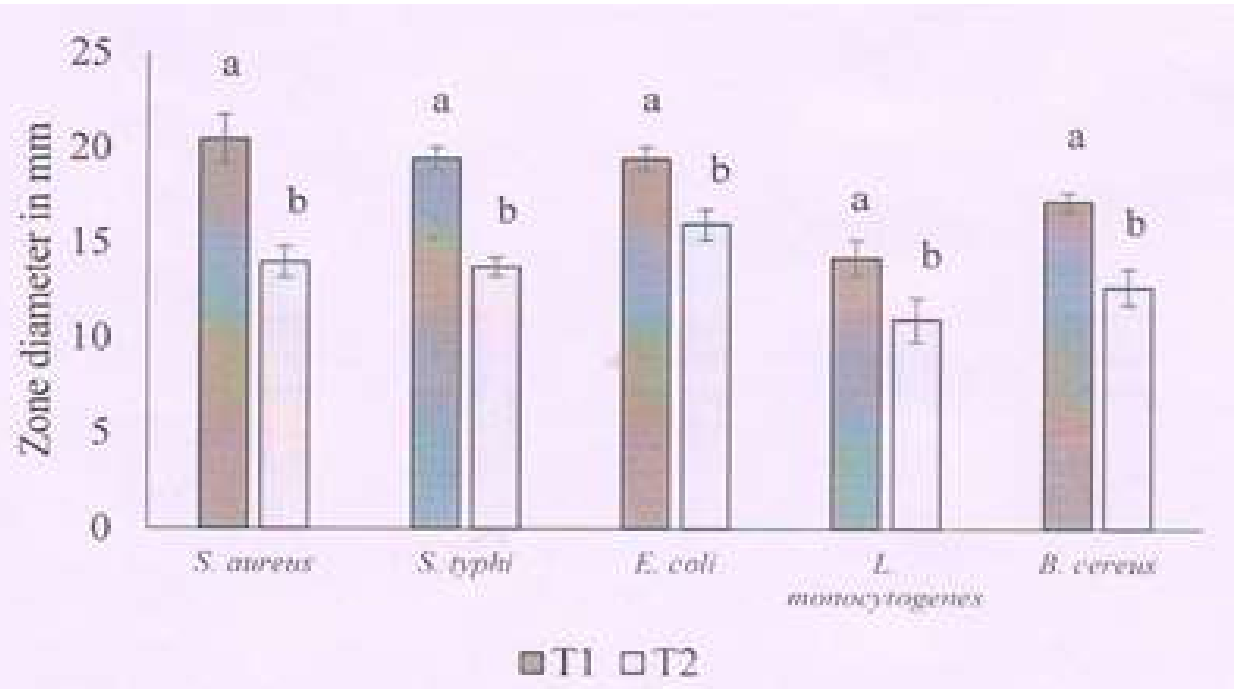

Table 3 Phytic acid and tannin content of finger millet flour and finger millet enriched fermented milk

\begin{tabular}{llc}
\hline Samples & \multicolumn{2}{c}{ Anti-Nutritional Factors } \\
\cline { 2 - 3 } & Phytic acid (\%) & $0.433 \pm 0.01^{\mathrm{a}}$ \\
\hline Unmalted finger millet flour & $0.291 \pm 0.005^{\mathrm{a}}$ & $0.354 \pm 0.02^{\mathrm{b}}$ \\
Malted finger millet flour & $0.174 \pm 0.005^{\mathrm{b}}$ & $0.066 \pm 0.00^{\mathrm{c}}$ \\
Finger millet enriched probiotic fermented milk & $0.094 \pm 0.002^{\mathrm{c}}$ & \\
\hline
\end{tabular}

The results are indicated as mean \pm standard deviation $(n=7)$. Different letters in the same column indicate significant differences $(\mathrm{p}<0.05)$.

Table 4 ACE Inhibitory, antioxidant and antidiabetic potential of fermented products

\begin{tabular}{|c|c|c|}
\hline Functional property & $\begin{array}{l}\text { Finger millet enriched } \\
\text { product }(\mathrm{T} 1)\end{array}$ & $\begin{array}{l}\text { Product without finger } \\
\text { millet(T2) }\end{array}$ \\
\hline ACE Inhibitory Activity (ACEi \%) & $51.54 \pm 0.03^{\mathrm{a}}$ & $51.11 \pm 0.04^{\mathrm{a}}$ \\
\hline Antioxidant activity [ABTS + Scavenging Activity $(\%)]$ & $95.59 \pm 0.50^{\mathrm{a}}$ & $52.37 \pm 6.29^{b}$ \\
\hline$\alpha$-Amylase inhibition $(\%)$ & $57.43 \pm 5.02^{\mathrm{a}}$ & $55.46 \pm 2.67^{\mathrm{a}}$ \\
\hline$\alpha$ - Glucosidase inhibition (\%) & $69.89 \pm 3.12^{\mathrm{a}}$ & $51.89 \pm 8.06^{\mathrm{b}}$ \\
\hline
\end{tabular}

Values show mean and standard deviation $(\mathrm{n}=7)$. Different letters in the same row indicate significant difference $(\mathrm{p}<0.05)$.

antinutritional factors like tannins and phytate. Geetha et al. (1997) found that malting reduced tannins and phytic phosphorus up to $54 \%$ and $58 \%$ respectively in brown finger millet. Antony and Chandra (1998) reported that phenolics decrease by $26-29 \%$, while tannins showed a more marked decrease of $44-52 \%$ by $48 \mathrm{~h}$ of fermentation. They attributed the reduction to the release of fiber bound tannins and polyphenol oxidase activity by fermenting microbes.

\section{Effect of incorporation of finger millet on antimicrobial activity}

The antimicrobial activity of finger millet enriched probiotic product and control is shown in Figure 1. The products showed promising antimicrobial activity against test pathogens. But the antimicrobial activity of finger millet enriched product (T1) was significantly $(p<0.05)$ higher than that of control $(\mathrm{T} 2)$ towards all the test pathogens. The zone of inhibition by $\mathrm{T} 1$ and $\mathrm{T} 2$ against
$S$. aureus was $20.50 \mathrm{~mm}$ and $14 \mathrm{~mm}$ respectively; and it was 19.50 and $13.75 \mathrm{~mm}$ respectively against $S$. typhi. The inhibition zone against $E$. coli by T1 and T2 were $19.50 \mathrm{~mm}$ and $16 \mathrm{~mm}$ respectively; and it was $14.25 \mathrm{~mm}$ and $11 \mathrm{~mm}$ against $L$. monocytogenes respectively. The inhibition zone against $B$. cereus by $\mathrm{T} 1$ and $\mathrm{T} 2$ were $17.25 \mathrm{~mm}$ and $12.75 \mathrm{~mm}$ respectively. Our study results showed that incorporation of finger millet significantly improved the antimicrobial activity of the resultant product compared to control which may be due to the action of antimicrobial substances from both milk and millet during fermentation of milk-millet mixture. The antimicrobial activity of fermented milk, in general, is said to be due to the lactic acid bacterial metabolites such as organic acids like lactic acid, bacteriocins, diacetyl, carbondioxide, etc (Mudgal, 2015). The probiotic strain used in this study is reported to possess significant antimicrobial activity against Bacillus 
cereus, Staphylococcus aeruginosa, Salmonella enterica serovar Typhi, and Escherichia coli (Prajapati et al. 2011). With respect to finger millet, its phenolic compounds, such as quercetin, gallic, caffeic, protocatechuic, para-hydroxy benzoic acid are reported to be responsible for its antimicrobial activity. (Chethan and Malleshi , 2007). Antimicrobial activity of germinated and ungerminated millet phenol extract against Bacillus cereus, Staphylococcus aureus, Yersinia enterocolitica, Escherichia coli, Listeria monocytogenes, Streptococcus pyogenes, Pseudomonas aeruginosa, and Serratia marcescens and Klebsiella pneumonia was reported by Chethan and Malleshi (2007). Quercitin is found to inhibit the growth of all the pathogenic bacteria, whereas gallic, caffeic, protocatechuic, para-hydroxy benzoic acid showed their antimicrobial activity towards few bacterial strains (Chethan and Malleshi , 2007). Seed coat phenolic extract from finger millet have been reported to inhibit pathogens including Bacillus cereus and Aspergillus niger (Viswanath et al. 2009). Antony et al. (1998) reported that fermented finger millet extract suppressed the growth of Salmonella sp. and Escherichia coli.

\section{Effect of incorporation of finger millet on ACE Inhibitory, antioxidant and antidiabetic activity}

\section{Effect on ACE Inhibitory activity}

ACE Inhibitory activity, antioxidant activity and antidiabetic activity of the finger millet enriched product (T1) and control (T2) is shown in Table 4. Average values for ACE inhibitory activity of $\mathrm{T} 1$ and $\mathrm{T} 2$ were found to be 51.54 and 51.11 per cent respectively. The difference in the ACE inhibitory activity of the samples were statistically not significant. Our results were in accordance with the reported literature. Research reports say that bioactive amino acid sequence displaying antihypertensive activity is mainly isolated from bovine and human milk caseins. Sun et al. (2009) reported that milks fermented by several strains of $L$. helveticus showed antihypertensive activity. ACE inhibitory peptides such as Val-Pro-Pro and Ile-Pro-Pro were identified from such fermented milks made using L. helveticus. Hati et al. (2015) evaluated ACE-inhibitory activities of eight different cultures. They suggested that Lb. helveticus MTCC 5463 and Lb. delbruckii (009) had ACE inhibitory activities and produced highest proteolytic zone in skim milk agar plate under optimized growth conditions. Sathya et al. (2017) studied the ACE inhibitory activity of fermented milk samples prepared by using seven different lactic acid bacterial cultures such as Lactobacillus helveticus, L. rhamnosus, L. delbruckii subsp. bulgaricus, L. plantarum, L. acidophilus, L. casei and L. paracasei subsp. paracasei. They found that ACE inhibitory activity ranged from 65.12 to 90.70 per cent. In their review on the current knowledge on Lactic Acid Bacteria (LAB) as cell factories for the production of bioactive peptides from a variety of food protein sources, Brown et al. (2017) mentioned that, LAB containing cell envelopeassociated proteinases are used as biocatalysts for the first step of casein breakdown releasing bioactive peptides during milk fermentation. Our study results showed that incorporation of finger millet do not have much contribution to the ACE inhibitory activity of the composite food. At the same time, the presence of finger millet did not interfere with the release of such peptides.

\section{Effect on antioxidant activity}

The products differed significantly $(\mathrm{p}<0.05)$ in their antioxidant activity. Average values for antioxidant activity of millet enriched product (T1) and control (T2) were found to be 95.59 and $52.37 \%$, respectively. Higher antioxidant activity of T1 may be due to the polyphenols present in the finger millet which is said to possess free radical scavenging activity. Phenolic acids and their derivatives, flavonoids and tannins present in the finger millet seed coat are of multifunctional and can act as reducing agents, metal chelators and singlet oxygen quenchers (Sripriya et al. 1996; Devi et al. 2014). Finger millet arabinoxylans have been shown to exhibit high antioxidant activities as a result of their bound phenolic acids such as ferulic acids (Chandrasekara and Shahidi 2011; Lafiandra et al. 2014). Ferulic acid is reported to exhibits very strong antioxidant, free radical scavenging and antiinflammatory activity (Devi et al. 2014).

\section{Effect on antidiabetic activity}

Incorporation of finger millet resulted in a significantly $(\mathrm{p}<0.05)$ higher $\alpha$-glucosidase inhibition activity, whereas the $\alpha$-amylase inhibition was not significant. The average values for $\alpha$-amylase inhibition of T1 and T2 were found to be 57.43 and $55.46 \%$, respectively. $\alpha$-glucosidase inhibition of T1 and T2 were found to be 69.89 and $51.89 \%$, respectively. Regular consumption of finger millet is known to reduce the risk of diabetes mellitus (Okoyomoh et al. 2013) and such property is attributed to its high polyphenols and dietary fiber contents (Shobana et al. 2013). Kavitha and Prema (1995) reported that the carbohydrates present in finger millet are slowly digested and assimilated than those present in other cereals. The beneficial effect of finger millet phenolics is due to partial inhibition of amylase and $\alpha$ glucosidase during enzymatic hydrolysis of complex carbohydrates and delayed absorption of glucose, which ultimately controls the postprandial blood glucose levels (Shobana et al. 2009). Beneficial effect of dietary fiber is usually attributed either to slower gastric emptying or formation of unabsorbable complexes with available carbohydrates in the gut lumen and these two properties might result in delayed absorption of carbohydrates and in the reduction of absolute quantity absorbed (Kawai et al. 1987; Rasmussen et al. 1991). Dietary fibers are categorized as water soluble and water insoluble. Chethan and Malleshi (2007) reported $15.7 \%$ insoluble dietary fiber, $1.4 \%$ soluble dietary fiber in finger millet grain, while Shobana and Malleshi (2007) reported 22.0\% total dietary fiber, 19.7\% insoluble dietary fiber and $2.5 \%$ soluble dietary fiber in finger millet. 
According to the current study results, incorporation of finger millet significantly increased the $\alpha$-glucosidase inhibitory activity. Reports have shown that the natural $\alpha$-amylase and $\alpha$ glucosidase inhibitors from plants to have lower inhibitory effect against $\alpha$-amylase activity and a stronger inhibitory activity against $\alpha$-glucosidase. Phytate is known to have $\alpha$-amylase inhibitory properties (Knuckles and Betschart, 1987) and a regulatory role in insulin secretion from pancreatic $\beta$-cells. Shobana et al. (2009) reported that finger millet phenolics are non-competitive inhibitors of intestinal $\alpha$-glucosidase and pancreatic amylase. As these inhibitors are proven modulators of postprandial glycaemia, they play a significant role in the management of diabetic complications. To our knowledge, there are no reports available on the in vitro anti-diabetic activity of milk-millet composite probiotic fermented product.

\section{Conclusions}

Enrichment of milk with finger millet and fermentation with starter culture enhanced the functional properties of resultant milk-millet composite probiotic fermented product. Incorporation of finger millet significantly improved the anti-microbial, antioxidant and antidiabetic potential of the composite product. However, incorporation of finger millet did not contribute to ACE inhibitory activity of the product. The process of malting and fermentation has significantly reduced the antinutritional factors phytic acid and tannin content in the product. The product was organoleptically acceptable with adequate probiotic count in that. The milk-millet composite probiotic fermented product has shown potential as a functional food.

\section{References}

Antony U, Chandra TS (1998) Antinutrient reduction and enhancement in protein, starch, and mineral availability in fermented flour of finger millet (Eleusine coracana). J Agrc Food Chem 46: 2578-2582

Antony U, Moses LG, Chandra TS(1998) Inhibition of Salmonella typhimurium and Escherichia coli by fermented flour of finger millet (Eleusine coracana). World J Microbiol Biotechnol14: 883-886

Begum PS, Madhavi G, Rajagopal S, Viswanath B, Razak MA, Venkataratnamma V (2017) Probiotics as Functional Foods: Potential effects on human health and its impact on neurological diseases. Int J Nutr Pharmacol Neurol Dis 7: 23-33

Brown L, Pingitore EV, Mozzi F,Saavedra L, Villegas JM, Hebert EM (2017) Lactic acid bacteria as cell factories for the generation of bioactive peptides. Protein Pept Lett 24: 146-155

Chandra D, Chandra S, Pallavi, Sharma AK (2016) Review of finger millet (Eleusine coracana (L.) Gaertn): A power house of health benefiting nutrients. Food Sci Hum Wellness 5: 149-155

Chandrasekara A, Shahidi F (2011) Inhibitory activities of soluble and bound millet seed phenolics on free radicals and reactive oxygen species. J Agrc Food Chem 59: 428-436

Chaudhary N, Vyas S (2014) Effect of germination on proximate composition and anti-nutritional factor of millet (ragi) based premixes. Int J Food Nutr Sci 3: 2320-7876

Chethan S, Malleshi NG (2007) Finger millet polyphenols: Optimization of extraction and the effect of $\mathrm{pH}$ on their stability. J Food Chem 105: $862-870$
Chung KT, Wong TY, Wei CI, Huang YW, Lin Y (1998) Tannins and human health: a review. Crit Rev Food Sci Nutr 38: 421-464

Delgado A, Brito D, Fevereiro P, Peres C, Marques JF (2001) Antimicrobial activity of $L$. plantarum, isolated from a traditional lactic acid fermentation of table olives. Le Lait 81: 203-215

Devi PB, Vijayabharathi R, Sathyabama S, Malleshi NG, Priyadarisini VB (2014) Health benefits of finger millet (Eleusine coracana L.) polyphenols and dietary fiber: a review. J Food Sci Technol 51: 10211040

Geetha Ramachandra TK, Virupaksha, Shadaksharaswamy M (1997) Relationship between tannin levels and in vitro - protein digestibility of finger millet (Eleusine coracana Gaertn). J. Agr Food Chem 25: 1101-1104

Gopalan A, Leversha MA, Satagopan JM, Zhou Q, Ahmadie HA, Fine SW, Eastham JA, Scardino PT, Scher HI, Tickoo SK, Reuter VE, Gerald WL (2009) TMPRSS2-ERG gene fusion is not associated with outcome in patients treated by prostatectomy. Cancer Res 4: 14001406

Gupta SM, Arora S, Mirza N, Pande A, Lata C, Puranik S, Kumar J, Kumar A (2017) Finger millet: a "certain" crop for an "uncertain" future and a solution to food insecurity and hidden hunger under stressful environments. Front Plant Sci 8: 643

Gupta N, Gupta AK, Singh NK, Kumar A (2011) Differential expression of PBF Dof transcription factor in different tissues of three finger millet genotypes differing in seed protein content and color. Plant Mol Biol Rep 29: 69-76

Hati S, Sreeja V, Solanki J, Prajapati JB (2015) Significance of proteolytic microorganisms on ACE-inhibitory activity and release of bioactive peptides during fermentation of milk. Indian J Dairy Sci 68 (6): 584-591

IS: 1479 (1960) Methods of test for dairy industry, part I: rapid examination of milk (FAD 19: dairy products and equipment). Indian Standards Institution, New Delhi, p. 29-30

IS: 1479 (1962) Methods of Test for Dairy Industry, Part III: Bacteriological Analysis of Milk. Rapid examination of milk, Indian Standards Institution, New Delhi, p. 25-39

Kavitha MS, Prema L (1995) Post prandial blood glucose response to meals containing different CHO in diabetics. Indian J Nutr Diet 32: 123126

Kawai K, Murayama Y, Okuda Y, Yamashita K (1987) Post prandial glucose, insulin and glucagon responses to meals with different nutrient compositions in NIDDM. Endocr J 34: 745-753

Knuckles BE, Betschart AA (1987) Effect of phytate and other myo inositol phosphate esters on $\alpha$-amylase digestion of starch. J Food Sci 52: 719-721

Lafiandra D, Riccardi G, Shewry PR (2014) Improving cereal grain carbohydrates for diet and health J Cereal Sci 59: 312-326

Lolas GM, Markakis P (1975) Phytic acid and other phosphorus compound of beans (Phaseolus vulgaris L.). J Agric Food Chem 23: 13-15

Mbithi-Mwikya, S, Van Camp J, Yiru Y, Huyghebaert A (2000) Nutrient and Antinutrient Changes in Finger Millet (Eleusine coracana) During Sprouting. Lwt-Food Sci Technol 33: 9-14

McCue P, Kwon YI, Shetty K (2005) Anti-amylase, antiglucosidase and anti-angiotensin I converting enzyme potential of selected foods. J Food Biochem 29: 278-294

McDonough CM, Rooney LW, Serna-Saldivar SO (2000) The millets. In: Kulp, K., Ponte, Jr., J.G. 2nd ed. Handbook of Cereal Science and Technology. Marcel Dekker, New York, p. 177-201

Mudgal S (2015) Functional Biomolecules and Food Ingredients Elaborated by LAB and their Potential Food Applications. In: Hati S, Mandal S and Mishra BK. Dairy Product Technology Recent Advances. Daya Publishing House, Division of Astral International Pvt. Ltd., New Delhi - 110 002. p. 283-307 
Okoyomoh K, Okere OS, Olowoniyiand OD Adejo GO (2013) Antioxidant and antidiabetic properties of Eleucine coracana (1.) geartn (finger millet) seed coat matter in streptozotocin induced diabetic rats. Int J Adv Herb Altern Med 1: 1-9

Phillippy BQ (2006) Transport of calcium across Caco-2 cells in the presence of inositol hexakisphosphate. Nutr Res 26: 146-149

Pinto MDS, Ghaedian R, Shinde R Shetty K (2010) Potential of cranberry powder for management of hyperglycemia using in vitro models. J Med Food 13: 1036-1044

Pore MS, Magar NG (1976) Effect of ragi feeding on serum cholesterol level. Indian J Med Res 64: 909-914

Prajapati JB, Khedkar CD, Chitra J, Senan S, Mishra V, Sreeja V, Patel RK, Ahir VB, Bhatt VD, Sajnani MR, Jakhesara SJ, Koringa PG, Joshi CG (2011) Whole-Genome Shotgun Sequencing of an Indian-Origin Lactobacillus helveticus Strain, MTCC 5463, with Probiotic Potential. J Bacteriol 193: 4282-4283

Rasmussen O, Winther C, Hermansen K 1991) Glycemic responses to different types of bread in IDDM patients: studies at constant insulinaemia. Eur J Clin Nutr 45: 97-103

Re R, Pellegrini N, Proteggente A, Pannala A, Yang M, Rice-Evans C (1999) Antioxidant activity applying an improved ABTS radical cation decolorization assay. Free Radical Bio Med 26: 1231-1237

Sathya P, Radha K, Sathian CT, Srinivasan C (2017) Angiotensin converting enzyme inhibitory activity from fermented goat milk produced with different lactic acid bacteria. Int J Curr Microbiol App Sci 6: 16701676

Shaikh MA, Sreeja V, Desai RR (2017) Effect of malted and unmalted finger millet flour and its rates of incorporation on quality attributes of finger millet enriched probiotic fermented milk product. Int $\mathrm{J}$ Curr Microbiol App Sci 6: 2258-2266

Shobana S, Malleshi NG (2007) Preparation and functional properties of decorticated finger millet (Eleusine coracana). J Food Eng 79: 529 538

Shobana S, Sreerama YN, Malleshi NG (2009) Composition and enzyme inhibitory properties of finger millet (Eleusine coracana) seed coat phenolics: mode of inhibition of alfa-glucosidase and alfa-amylase. J. Food Chem 115: 1268-1273

Shobana S, Krishnaswamy K, Sudha V, Malleshi NG, Anjana RM, Palaniappan L, Mohan V (2013) Finger millet (Ragi, Eleusine coracana L.): a review of its nutritional properties, processing, and plausible health benefits. Adv Food Nutr Res 69: 1-39
Sripriya G, Chandrasekharan K, Murty VS, Chandra TS (1996) ESR spectroscopic studies on free radical quenching action of finger millet (Eleusine coracana). Food Chem 57: 537-540

Steel RGD, Torrie JH (1980) Principe and procedures for statistics- A Biometric approach. 2nd ed. McGraw - Hill, New York, p. 137-167

Stone H, Sidel JL (2004) Sensory evaluation practices. 3rd ed. Tragon Corporation, Ca. USA.

Sun T, Zhao SP, Wang H (2009) ACE-inhibitory activity and gamma aminobutyric acid content of fermented skim milk by Lb. helveticus isolated from Xinjiang koumiss in Chaina. Eur Food Res Technol 228: $607-612$

Swain T, Hillis WE (1959) The phenolic constituents of Prunus domestica. I. The quantitative analysis of phenolic constituents. J Sci Food Agric 10: 63-68

The Gazette of India (2018) Ministry of agriculture and farmers welfare notification. New Delhi, F. No. 4-4/2017-NFSM (E). p. 2.

Tripathi B, Platel K (2010) Finger millet (Eleucine coracana) flour as a vehicle for fortification with zinc. J Trace Elem Med Bio 24: 4651

Varsha V, Asna U, Malleshi NG (2009) Evaluation of antioxidant and antimicrobial properties of finger millet polyphenols (Eleusine coracana). Food Chem 114: 340-346

Veenashri BR, Muralikrishna G (2011) In vitro anti-oxidant activity of xylo-oligosaccharides derived from cereal and millet brans-A comparative study. Food Chem 126: 1475-1481

Verma V, Patel S (2013) Value added products from nutri-cereals: finger millet (Eleusine coracana). Emir J Food Agric 25: 169-176

Viswanath V, Urooj A, Malleshi NG (2009) Evaluation of antioxidant and antimicrobial properties of finger millet polyphenols (Eleusine coracana). Food Chem 114: 340-346 